\title{
AN INTERESTING DECUBITUS ULCER CLOSURE
}

\author{
By A. Estin Comarr, M.B., M.D., F.A.C.S., F.I.C.S., D.A.B.
}

From the Spinal Cord Injury Service, Veterans Administration Hospital, Long Beach, California, and the Department of Surgery, School of Medicine, Loma Linda University, Los Angeles, California

Closure of decubitus ulcers is not necessarily a plastic surgical but rather a general surgical procedure; it is practised in various ways at different Spinal Cord Injury Centres. In the light of our experience at this Centre (Bors, I945, 1948; Bors \& Comarr, I948; Comarr, I948, I949, I95 I, I957, I958, I959; Comarr \& Bors, I95 I), the rule that only flaps (Blocksma et al., I949; Conway et al., I956; Kahn, I960; Osborne, I955; Yeoman et al., I954) can be used in weight-bearing areas has been dispelled. Many a well-done flap, rotated elsewhere, was found to have broken down at the site of weight bearing, while the majority of scars have stood up well. This should not imply that we are averse to flap procedures of any sort where and when they become indicated.

Thus, in the majority of our decubitus closures, the retention wire button technique has been the method of choice for the past 18 years. Elliptical excision with straight or S-shaped closure is most frequently practised (fig. I). T- or Y-

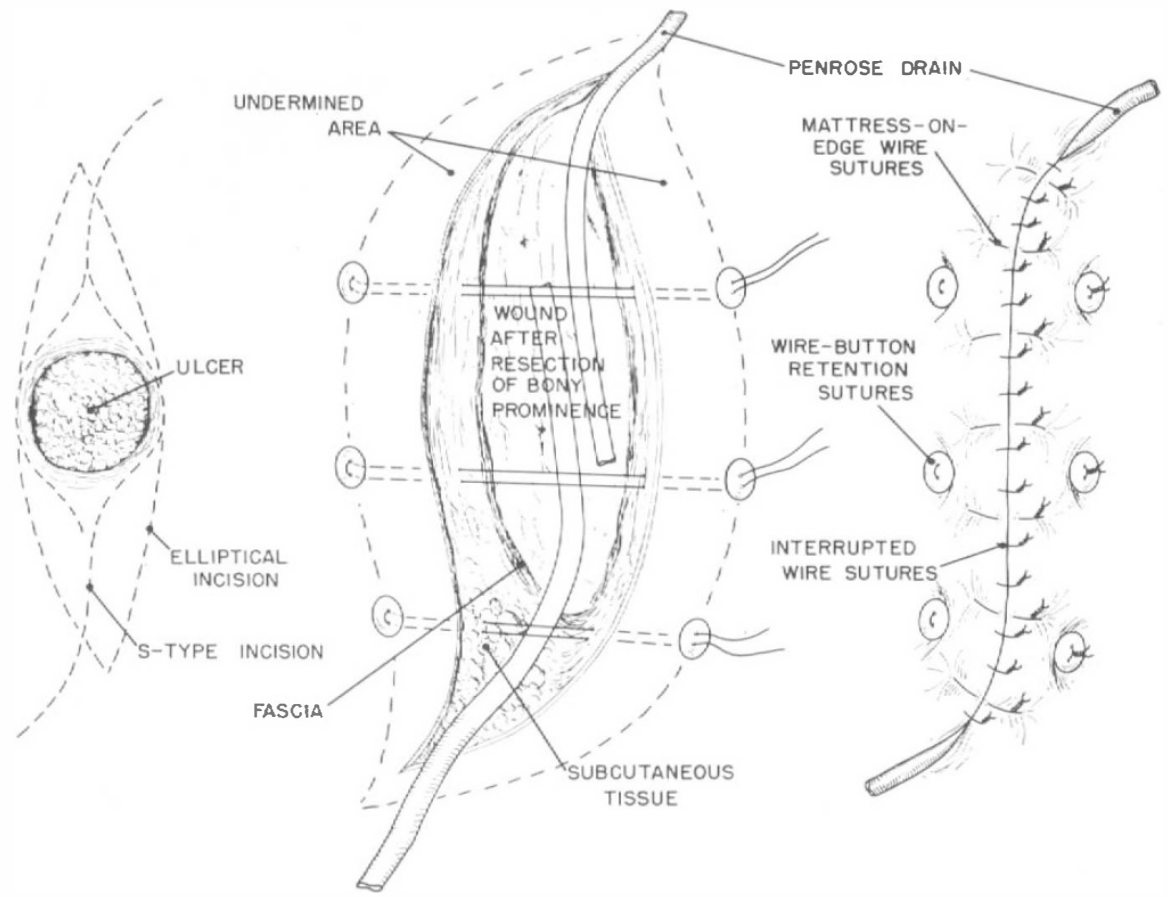

FIG. I

(From A. E. Comarr, (1957), F. Indian med. Prof. 4, I560, reproduced by permission of the editor.) 
shaped closures have their place at sacral sites. Partial ostectomy is added when indicated. Healthy bone need not be resected lest it interferes with wound approximation. These 'simple' closures require wide mobilisation of the skin by undermining with scissors or scalpel between subcutaneous tissue and muscle or fascia. The wound edges meet easily without tension by bilateral hand pressure ("hand test'). Bleeding from all structures, soft tissue and bone, is controlled by electrofulguration with the exception of rare large vessels. Retention wire button sutures are then introduced using stainless steel wire (26-28 gauge). From two to four such retention sutures are used depending on the size of the wound. The latter include the undermined skin and subcutaneous tissue; but not the underlying fascia or muscle. The buttons are placed about $4 \mathrm{~cm}$. from the wound edge. Penrose drains provide adequate drainage; they are introduced either by puncture wounds or at either wound angle. This type of closure puts the tension on the button line; the sutures of the wound edges serve only approximation without tension.

The success of closure depends on the following factors: (I) the general condition of the patient must be good, (2) no excessive spasticity must be present, (3) the ulcer must show clean granulation, and (4) good judgment is necessary to determine whether the size of the ulcer will allow simple closure.

Mr. M. C., age 4I, was in good health until 7.7.6I, when he noticed tingling in both feet. Within the next few days he felt 'as if both legs were asleep'. By 7.I0.6I he had noticed some 'loss of control' of both lower extremities and had to 'hold on to the walls' in order to keep his appointment at a local hospital wherein a myelogram was performed. The myelogram was reported as negative. By the following day he was 'completely paralysed' and has had no neurological improvement. Examination in September of 1962 revealed that the patient had a complete lesion below the 4 th thoracic segment. The diagnosis was infectious transverse myelitis.

Shortly after entrance into a local hospital in July of I96I, he began to develop the decubitus ulcer we are to describe. Without including the marginal epithelialised area, the ulcer measured about $7 \mathrm{~cm}$. in length by $3 \frac{1}{2} \mathrm{~cm}$. at its greatest width. The depth of the wound increased inferiorly following the course of the sacrum to a depth of $4 \mathrm{~cm}$. In the depth rough bony spurs were palpable. At the superior and medial side of the ulcer was a well-healed scar measuring about $3 \mathrm{~cm}$. in diameter (fig. 2).

A retention wire button closure was done on 9.12.62 without including the old scar in the excision in order not to jeopardise the result by applying a retention button near the anal site. The ulcer was excised as shown in Figure 3; the bony spurs were removed by chisel and mallet. The arrows indicate the undermined area, which included the scar. Approximation was easy, as seen in Figure 4; the scarred area was expected to necrose, but this meant only that the deep and extensive ulcer of long standing would be transposed to a small sacral site, more favourable for healing. The first dressing was performed on the 7 th post-operative day; as anticipated the old scar had broken down and drainage was coming from this site rather than from the penrose drain, which therefore was removed. A new small shallow ulcer developed at the site of the scar. Figure 5, taken a month later, shows marginal epithelialisation of the sacral ulcer with only a superficial defect. Within a week the ulcer measured only I cm. in diameter (fig. 6). Figure 7 shows the final result which has remained healed over a year. 


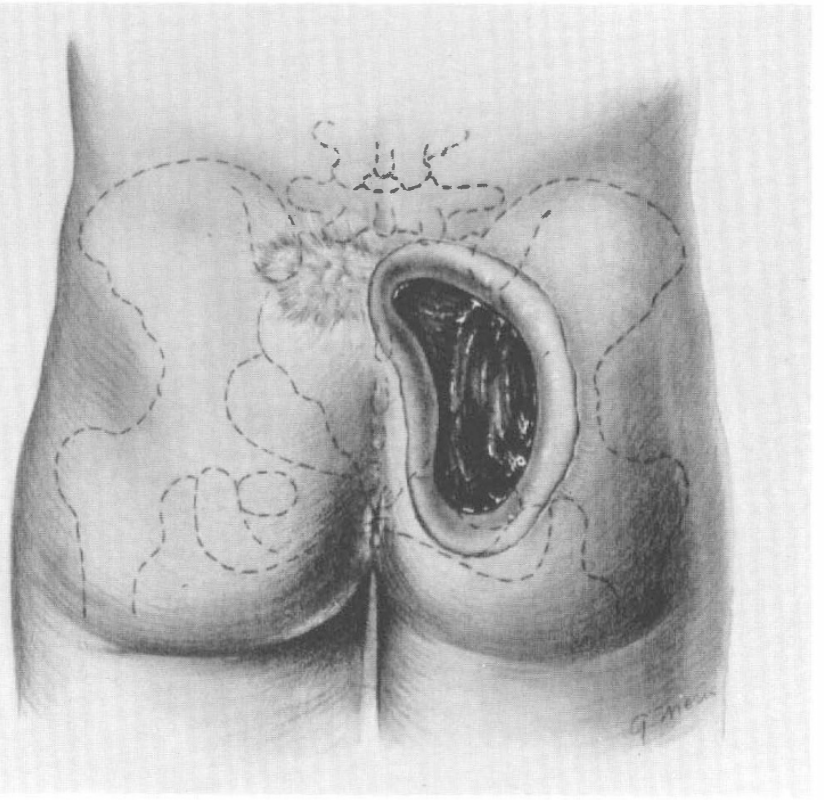

FIG. 2

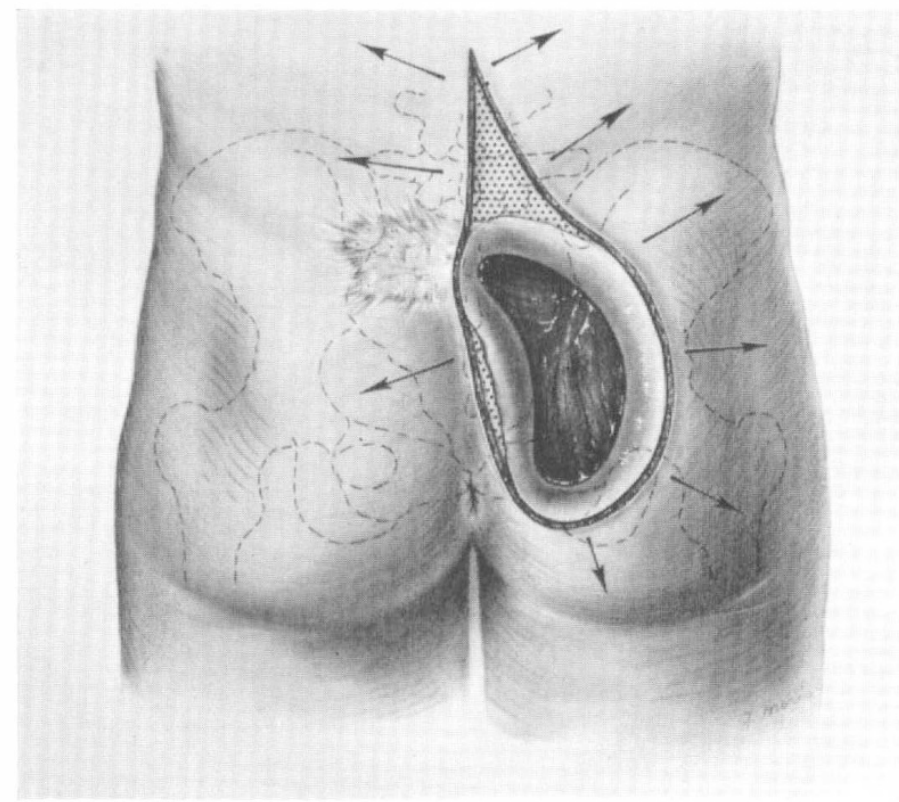

FIG. 3 


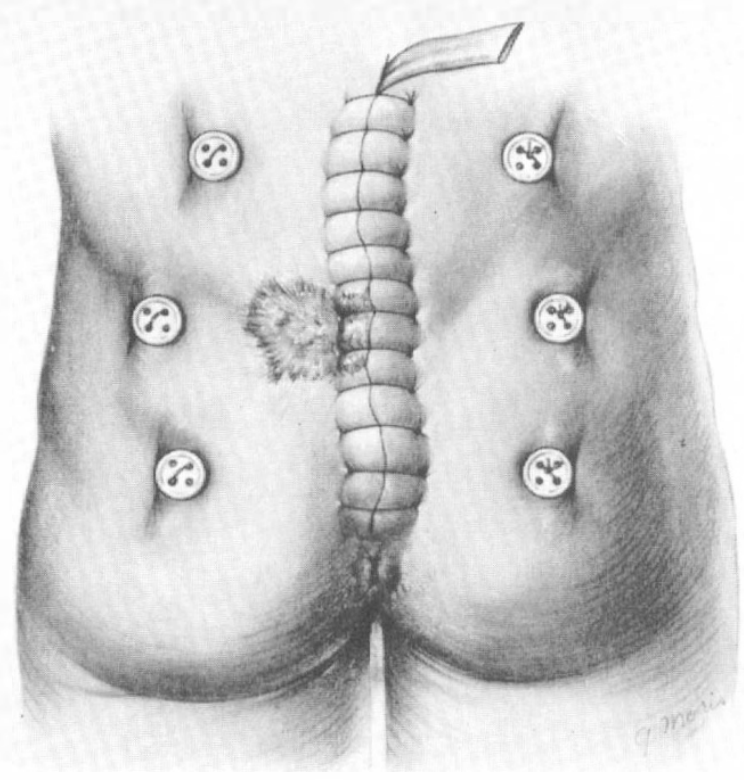

FIG. 4

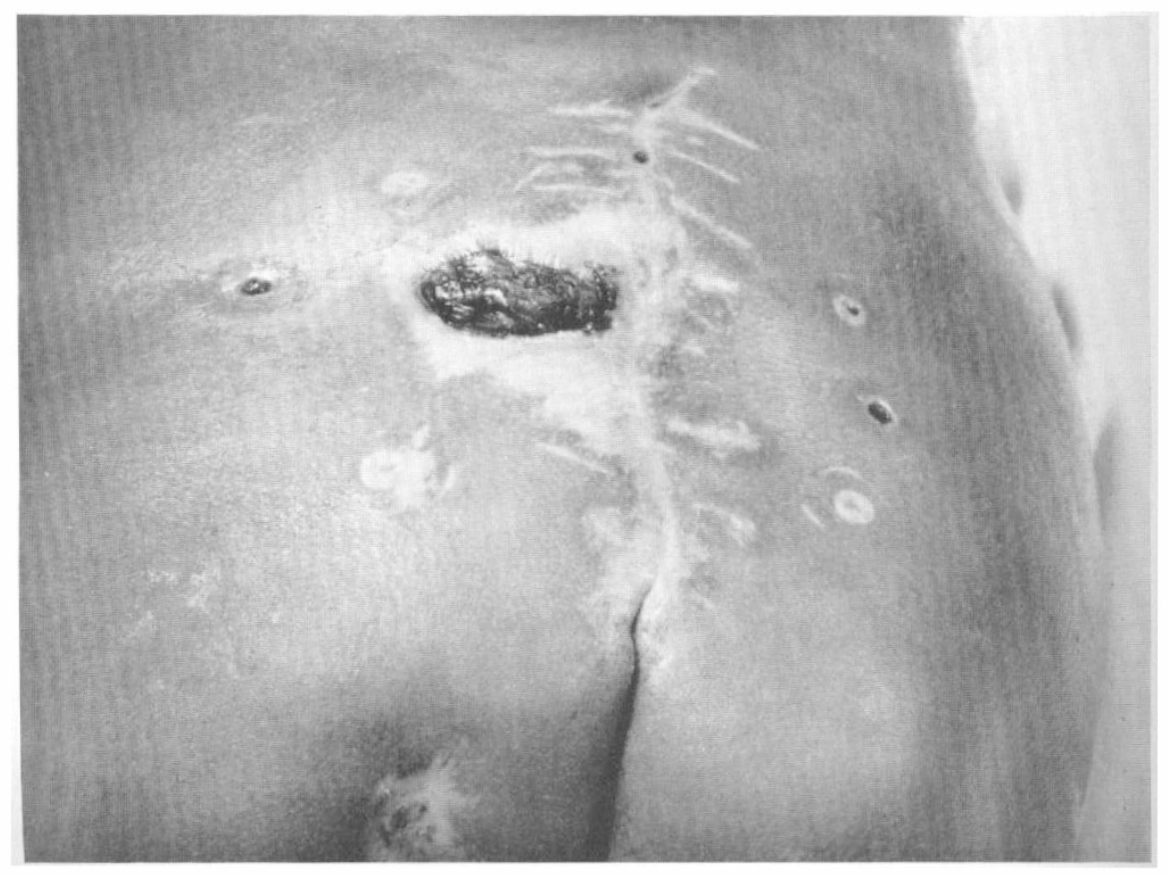

FIG. 5 


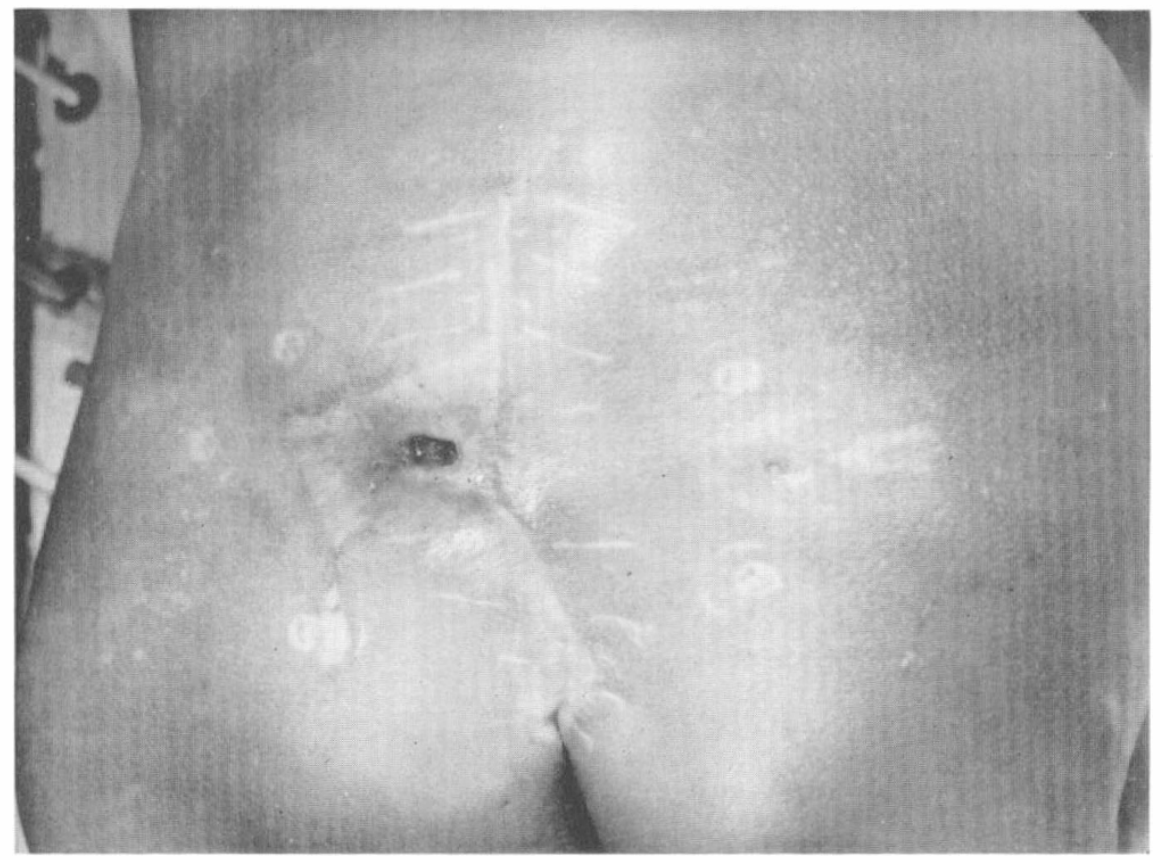

FIG. 6

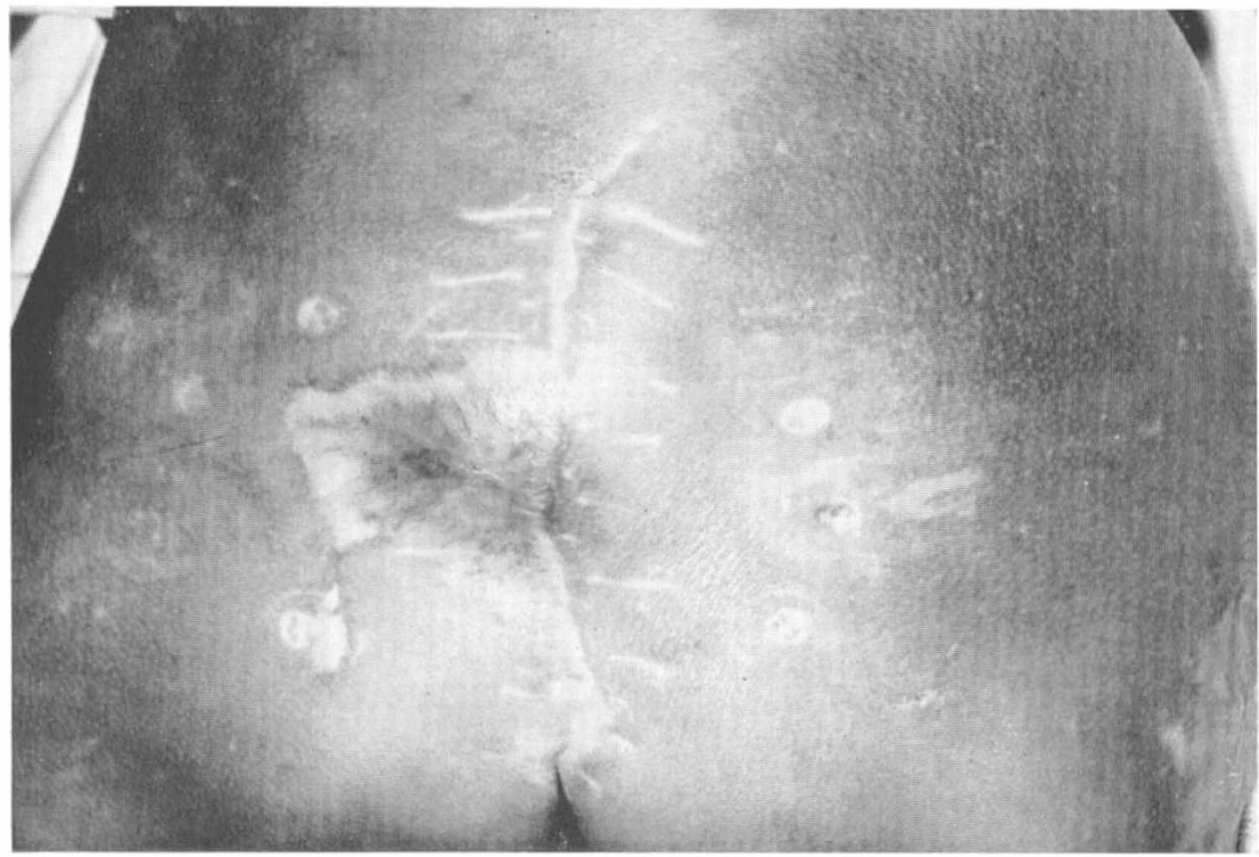

FIG. 7 


\section{DISCUSSION}

Doubts of the plastic surgeons to apply rotation flaps, although accustomed to use this method, were justifiable. They were afraid of severe complications around the anal site. By our type of closure we not only avoided complications but saved time since this closure was performed in one stage, including the removal of bone. Per contra, flap procedures of that magnitude would have required at least two stages. Healing progressed well without using even buried grafts (Braun,I920; Wangensteen, I930).

\section{SUMMARY}

A decubitus ulcer at an unusual site was successfully treated by means of the 'simple' closure with retention wire button technique at the risk of creating another small ulcer, which healed spontaneously.

\section{RÉSUMÉ}

Une éscharre située à un endroit inhabituel a été traitée avec succès grâce à une fermeture 'simple', retenue par la technique du fil d'acier maintenu à la peau par des boutons, au risque de créer un autre petit ulcer qui guérit spontanément.

\section{ZUSAMMENFASSUNG}

Ein Dekubitus in einer ungewöhnlichen Situation wurde erfolgreich mit einer Technik geschlossen, die sich mehrerer Draht-Entspannungsnähte bedient. Ein dabei auftretender kleiner weiterer Epitheldefekt heilte spontan.

\section{REFERENCES}

Blocksma, R., Kostrubala, J. G., \& Greeley, P. W. (1949). Plast. reconstr. Surg. 4, I23. Bors, E. (1945). Transverse Myelitis Conference, 9th Service Command, Hammond General Hospital, Modesto, California. War Department.

Bors, E. (I948). Veterans Administration Technical Bulletin. TBIO-503. Washington, D.C. Bors, E., \& Comarr, A. E. (1948). Surg. Gynec. Obstet. 86, 68.

Bors, E., \& COMARR, A. E. (I948). Surgery, 24, 680.

BRAUn, Wilhelm (I920). Zbl. Chir. 52, I555.

Comarr, A, E. (1948). Staff Meeting, Birmingham General Hospital, Van Nuys. California: Veterans Administration.

Comarr, A. E. (I949). Ann. West. Med. Surg. 3, 235.

Comarr, A. E. (I95I). F. Amer. med. Ass. 146, 229.

Comarr, A. E. (1957). F. Indian med. Prof. 4, I560.

Comarr, A. E. (I958). F. Indian med. Prof. 5, 2307.

Comarr, A. E. (I958). F. Indian med Prof. 5, 2354.

Comarr, A. E. (I958). F. Indian med. Prof. 5, 2379.

Comarr, A. E. (I958). F. Indian med. Prof. 5, 2464.

Comarr, A. E. (1959). F. Indian med. Prof. 5, 2496.

Comarr, A. E. (I959). F. Indian med. Prof. 5, 2528.

Comarr, A. E. (I959). F. Indian med. Prof. 5, 2569.

Comarr, A. E., \& Bors, E. (I95I). Ann. west. Med. Surg. 5, 210.

Conway, H., \& Griffith, B. H. (I956). Amer. F. Surg. 9I, 946.

Kahn, Sidney (1960). Surg. Clin. N. Amer. 40, i657.

OSBORNe, Rowland (I955). Brit. F. plast. Surg. 8, 2 I 4.

WangensteEn, O. H. (I930). Surg. Gynec. Obstet. 50, 634.

Yeoman, M. P., \& Hardy, A. G. (I954). Brit. F. plast. Surg. 7, I79. 